\title{
Teatr $i$ wychowanie (Theatre and Upbringing) Authors: Krzysztof Homa, Justyna Sprutta, Weronika Pudełko, Katarzyna Skulska
}

„Każda inscenizacja teatralna, bez względu na jej miejsce, rozwija intelektualnie, pobudza refleksyjność, uwrażliwia, kompensuje niedostatek codziennej egzystencji, kreuje postawy etyczne, wzbogaca doznania estetyczne, pozwala na marzenia, uczy dokonywania wyborów, aktywizuje do przejścia z bierności (obojętności) do działania indywidualnie i społecznie użytecznego" — piszą Halina Guzy-Steinke i Teresa Wilk w swojej książce na temat szkolnej edukacji teatralnej pt. Uczeń i teatr. Realia a poszukiwania możliwości realizacji edukacji teatralnej w szkole (Toruń 2009). Teatr oddziałuje w niezwykły i wszechstronny sposób na człowieka - i to zarówno wtedy, gdy jest on biernym widzem, jak i wówczas, gdy czynnie angażuje się w działania teatralne. W obu przypadkach teatr kształci go i wychowuje, pomaga mu zrozumieć siebie i innych.

Wychowawczo-dydaktyczny walor teatru dostrzeżono już w minionych wiekach, czego sztandarowym przykładem może być protestancki teatr szkolny okresu humanizmu, który w drugiej połowie XVI wieku przyjął formę zinstytucjonalizowaną dzięki włączeniu sztuki teatralnej do systemu edukacji, jak też nieco późniejsze słynne barokowe sceny religijne w szkołach prowadzonych przez jezuitów czy pijarów. W naszych czasach zainteresowanie teatrem jako medium kształcenia, wychowania i formacji - także religijnej — jest równie wielkie. Świadczą o tym liczne publikacje na temat kształcenia i wychowania dzieci i młodzieży, szkolnych teatrów amatorskich, oddziaływania sztuki teatralnej na osobowość uczniów, inscenizacji jako jednej z form pracy nauczyciela z uczniem czy miejsca i roli form teatralnych w pracy opiekuńczo-wychowawczej w świetlicach szkolnych, jakie ukazały się na rynku wydawniczym w minionych dziesięcioleciach. Są to prace o charakterze zarówno teoretycznym, jak i praktycznym - 
w postaci podręczników, poradników i zbiorów materiałów do wykorzystania w konkretnej działalności edukacyjno-wychowawczej czy duszpasterskiej.

Ten niemały zbiór literatury na temat wychowania przez teatr powiększył się o opublikowaną w krakowskim Wydawnictwie Naukowym Akademii Ignatianum pracę wieloautorską pt. Teatr $i$ wychowanie. Monografia rozpoczyna się krótkim wstępem, napisanym przez Justynę Spruttę. Dalej następuje zasadnicza część książki, którą tworzy sześć rozdziałów podejmujących problematykę teatru w różnych aspektach. Pierwszy z nich, autorstwa jezuity, Krzysztofa Homy, noszący tytuł Misteria w piatej księdze „Adversus Nationes” Arnobiusza z Sicca, traktuje o historii teatru europejskiego. Rozpoczyna się ona od teatru starożytnej Grecji, zrodzonego z pogańskich misteriów religijnych, które autor przybliża czytelnikowi przez odwołanie się do ich opisu, jaki pod koniec III wieku zawarł w swojej apologii chrześcijański retor i pisarz Arnobiusz. Dwa następne rozdziały, autorstwa Justyny Sprutty, dotyczą kolejno historii teatru powszechnego i polskiego oraz dziejów i repertuaru polskich teatrów szkolnych ze szczególnym uwypukleniem teatru jezuickiego. Czwarty rozdział, napisany przez Katarzynę Skulską, został poświęcony istocie teatru i wybranym gatunkom teatralnym oraz parateatralnym. Piąty rozdział — jeszcze raz autorstwa Justyny Sprutty przedstawia teatr w sztukach plastycznych na podstawie wybranych, mniej lub bardziej znanych dzieł sztuki, w których obecna jest problematyka teatralna. Autorka wychodzi od starożytnej sztuki greckiej, a kończy na obrazie Teatr dziecięcy (1931) polskiego malarza Tadeusza Makowskiego, żyjącego i tworzącego w Paryżu na przełomie XIX i XX wieku. Ostatni rozdział - napisany przez Weronikę Pudełko - ukazuje teatr w procesie dydaktyczno-wychowawczym. Autorka mówi w nim o wychowawczej, a w szczególności o terapeutycznej funkcji teatru. Refleksję teoretyczną tej książki dopełnia obszerny spis bibliograficzny i netograficzny, jak też aneks, na który składają się piękne fotografie dzieł sztuki przedstawiających teatr.

Monografia ma w całości wartość naukową. Poszczególne rozdziały są dobrze umocowane w źródłach i literaturze przedmiotu, jak też opatrzone rzetelnie sporządzonymi przypisami. Autorom tekstów należy się uznanie za zachowanie jednolitości terminologicznej, co w wypadku bardzo szerokiej, wręcz trudnej do ogarnięcia refleksji nad teatrem nie było z pewnością łatwe. Czy jednak praca ta spełnia wymóg odpowiedniości pomiędzy jej tematem (tytułem) i założonym w nim problemem a jego rozwinięciem w kolejnych jej częściach? Gdyby wziąć pod uwagę jedynie spis treści zapowiadający tylko dwa teksty odnoszące się bezpośrednio do tematu wychowania przez teatr, trzeba by odpowiedzieć na powyższe pytanie przecząco. Jednakże każdy, kto zagłębi się w treść wszystkich tekstów tworzących tę książkę, łatwo zobaczy, że traktuje ona cały czas o kształceniu i wychowaniu: wtedy, gdy prezentuje początki i dzieje teatru, gdy mówi o obecności teatru w sztukach plastycznych i wtedy, gdy konkretnie pokazuje, jak wy- 
korzystać tę niezwykłą, prastarą sztukę w jej niezliczonych formach w procesie kształcenia, wychowywania i formowania człowieka. W tym sensie stanowi ona cenną pomoc dla wszystkich, którzy dostrzegają niezwykłą więź łączącą teatr i wychowanie.

Justyna Sprutta napisała we wstępie, że „monografia nie wyczerpuje tematu, ale nie jest też jedynie szkicem o teatrze". Nie sposób się z tym nie zgodzić. W przypadku teatru trudno bowiem zarówno „wyczerpać” temat, jak i tylko „otrzeć się" o tak bogatą i przyciągającą rzeczywistość, o której Stanisław Wyspiański pisał: „Teatr mój widzę ogromny, wielkie powietrzne przestrzenie, ludzie je pełnią i cienie, ja jestem grze ich przytomny" (I ciagle widzę ich twarze, 1904).

Wszystkie prace składające się na tę monografię są interesujące, wnikliwe i zasługują na uznanie. Nie sposób jednak nie wyróżnić tu jednego tekstu. Jest nim artykuł Justyny Sprutty o teatrze w sztukach plastycznych, który daje czytelnikowi nową, zaskakującą perspektywę patrzenia na teatr - spojrzenia przez pryzmat innych sztuk.

Wartość recenzowanej książki polega przede wszystkim na tym, że uzmysławia ona czytelnikom, iż udział w kulturze ma bardzo duży wpływ na osobowość człowieka, zwłaszcza młodego. Uczy go wrażliwości, przeżywania, rozumienia wartości, co ma szczególną wagę w obecnych czasach tzw. kultury masowej. Novalis, niemiecki poeta wczesnego romantyzmu napisał, że „teatr to aktywna refleksja nad samym sobą" (Fragmenty, 1797). Do takiej refleksji — dzięki zamieszczonym tekstom o teatrze i wychowaniu oraz dzięki wyrażonej wprost i nie wprost zachęcie do chodzenia do teatru i jego tworzenia — zaprasza ta książka i już z tego względu dobrze się stało, że została opublikowana.

Adam Kalbarczyk ${ }^{1}$

Adam Mickiewicz University, Poznan, Poland

\footnotetext{
${ }^{1}$ Rev. Adam Kalbarczyk - priest of the Archdiocese of Poznań, PhD with a postdoctoral degree in theology, Associate Professor of homiletics at the Faculty of Theology of Adam Mickiewicz University in Poznań; member of the Society of Friends of Science in Poznań; German philology specialist, translator; author of several books and articles on pastoral theology and theology of preaching; his interests focus on homiletic rhetoric, the so-called 'children's theology', the relationship between the theatre and preaching, the ministry of the word by the laity, and the history of Protestant preaching in the period of Lutheran orthodoxy; e-mail: adamkal@amu.edu.pl. ORCID: 0000-0002-3749-2497.
} 


\begin{abstract}
The book Teatr $i$ wychowanie (Theatre and Upbringing) by Krzysztof Homa, Justyna Sprutta, Weronika Pudełko and Katarzyna Skulska presents the history of the theatre, its essence, typology, as well as the role of the theatre in upbringing and therapy, especially for children.

This book demonstrates, among others:

- Greek mysteries as the beginning of the European theatre,

- the history of the theatre in the world and Poland,

- the school theatre in the past and present,

- the essence of the theatre, as well as theatrical and paratheatrical genres.

Moreover, in this book examples of paintings presenting the theatre are displayed. The reviewed book is a multi-author monograph.
\end{abstract}

\title{
Keywords
}

theatre, upbringing, therapy, religious formation

\section{Słowa kluczowe}

teatr, wychowanie, terapia, formacja religijna 